\author{
Barbara Danowska-Prokop \\ Department of Economics \\ University of Economics in Katowice \\ e-mail: barbara.danowska-prokop@ue.katowice.pl \\ ORCID: 0000-0002-5030-9220
}

\title{
THE GREAT DEPRESSION IN THE EYES OF THE SILESIAN CHRISTIAN DEMOCRATS
}

\begin{abstract}
Goal - The great depression forced changes in the economic program of the Christian Democracy (Silesian Christian Democrats). Indicating the exceptional role of the Upper Silesian heavy industry in the economic potential of the Second Polish Republic, the program emerged from the criticism of the Sanation (Sanacja in Polish) program of surviving the crisis.

Research method - The study analyzes archival sources and literature on the subject, as well as statistical data.

Results - In the years of the great depression, official state authorities, as well as individual political groups formulated their own programs for overcoming the economic difficulties that were faced. Christian Democracy was one of these groups, but its program to combat the crisis was limited only to ad hoc measures aimed at mitigating the negative effects of the crisis. The activists of the Silesian Christian Democrats did not properly interpret the sources of economic difficulties, as they did not understand the core of the problem.

Keywords: economic crisis, economic program, Christian Democracy.
\end{abstract}

\section{Introduction}

The first signs of an economic slowdown in the Polish economy were observed at the turn of 1928/1929, when an increase in stocks of unsold goods, as well as a slowdown in the pace of inflow of orders both from the private and public sectors were reported. They adversely affected the level of utilization of the possessed production potential and its efficiency. In the late fall of 1929, the crisis became a reality, which was confirmed by the industrial production and employment rate.

In the case of the Upper Silesian industry, the crisis was fully apparent only in the first half of the following year. Growing economic difficulties started the process of decline in the level of industrial and agricultural production, and consequently decrease in the employment and income of hired 
workers. Thus, the worsening economic situation contributed to the deterioration of working conditions and pay, and this in turn had a negative impact on the living conditions of employees working in Upper Silesian enterprises, as well as on the attitude towards the Polish state.

The deteriorating economic conditions on the national and international level forced the Christian Democracy (Silesian Christian Democrats) to act and develop an economic program, adapted not only to the specific realities of Upper Silesian economic and socio-political life, but also to international situation.

\section{The great depression and the situation of the Upper Silesian industry}

In the realities of Upper Silesia, i.e., the domination of modern heavy industry and foreign capital (especially German), the economic crisis meant serious difficulties in the sphere of production and finance. It was associated with a deterioration in the level of utilization of the production potential and, respectively, a decline in the production volume and the profit rate. The deterioration of the financial situation of the local industry was observed, as almost all Upper Silesian enterprises experienced greater or lesser financial losses, which simply led to an increase in their debt to foreign (especially German) financial institutions. Poor financial condition (payment gridlocks and growing tax liabilities) contributed to fiercer competition and the elimination of unprofitable producers from the market. Consequently, the cartelization process was accelerated [Danowska-Prokop, 2012, pp. 88-97; Danowska-Prokop, Zagóra-Joniasto, 2017, pp. 63-84; Grzyb, 1978, p. 139]. Unfavorable trends in the economic situation left their mark on the level of industrial production, which is confirmed by the data presented in Table 1.

The data presented in the table clearly show that in 1929 the time of prosperity in the Upper Silesian coal, steel and metallurgical industries ended (the crisis affected mainly the raw materials industry and sectors producing for export). From the spring of 1930, as the crisis intensified, the demand for hard coal on the domestic and foreign markets decreased. Throughout the year, only 17 million tons were sold on the domestic market (the demand shrank by as much as $23.3 \%$ ) and only over 10 million tons were exported (export decreased by $8.7 \%$ year on year). In this situation, producers reduced coal mining by almost $18 \%$, which adversely affected the profitability of the industry [Danowska-Prokop, 2012, pp. 88-97; Dobis, 
The Great Depression in the Eyes of the Silesian Christian Democrats

Table 1

Production volume of selected products of the Upper Silesian industry in $1929-1933(1928=100)$

\begin{tabular}{|c|c|c|c|c|c|}
\hline Year & $\begin{array}{c}\text { Hard coal } \\
\text { mining }\end{array}$ & $\begin{array}{c}\text { Production } \\
\text { of pig iron }\end{array}$ & $\begin{array}{c}\text { Steel } \\
\text { production }\end{array}$ & $\begin{array}{c}\text { Zinc } \\
\text { production }\end{array}$ & $\begin{array}{c}\text { Lead } \\
\text { production }\end{array}$ \\
\hline 1929 & 112.4 & 102.7 & 95.5 & 104.6 & 96.6 \\
\hline 1930 & 92.5 & 69.8 & 96.4 & 112.6 & 108.5 \\
\hline 1931 & 94.4 & 57.4 & 60.5 & 88.0 & 84.7 \\
\hline 1932 & 70.6 & 32.0 & 27.8 & 60.0 & 31.8 \\
\hline 1933 & 65.5 & 51.6 & 62.6 & 58.9 & 32.7 \\
\hline
\end{tabular}

Source: AP Katowice, UWŚL/PH 232, pp. 33-38; UWŚL/PH 1303 II, p. 310.

1931, issue 9, pp. 382-387; Popkiewicz, Ryszka, 1959, pp. 266-267]. The decreasing trend continued in the following years, with the overall industrial production rate reaching the lowest value in 1932 ("the bottom of the crisis"). In these circumstances, Silesian coal producers made efforts to attract foreign buyers on markets not covered by the regulations of licenses of the Polish Coal Convention (Denmark, Ireland, Sweden, Norway, Finland, Latvia, Belgium and France). Consequently, they established the Export Convention (the Convention operated under the Polish Coal Convention). A special Equalization Fund was created at the Export Convention, from which subsidies for exporters of this raw material were paid. In this way, the Fund promoted the export of Upper Silesian coal by sea (through the ports in Gdynia and Gdańsk) to countries not covered by the license [Dobis, 1932, issue 9, pp. 353-358; Jaros, 1974, pp. 70-80; Popkiewicz, Ryszka, 1959, pp. 268, 303-305].

In the Upper Silesian steel industry, the symptoms of the emerging crisis occurred as early as 1929 (data are presented in Table 1). In 1929, steel production decreased to $95.5 \%$ of the level of 1928 . The decline in demand on the domestic market encouraged producers of steel products to seek buyers on foreign markets. However, relatively high production costs translated into the prices of steel products, which in turn weakened their competitiveness on foreign markets and limited exports. During the crisis years, production in the basic sectors of the steel industry showed a declining trend, with observed temporary positive deviations from the downward trend [Horowitz, 1932, No. 3, pp. 51-52; Popkiewicz, Ryszka, 1959, pp. 272-275, 310-311; Wanatowicz, 1970, pp. 385-423; Wiliński, 1930, pp. 5-7]. 
Equally unfavorable trends occurred in other branches of the Upper Silesian industry, especially in the zinc and lead, machinery, chemical, processing, food and construction industries. Insufficient effective demand for the products of the Upper Silesian industry on the domestic and foreign markets was reflected in the declining industrial production index and in the deterioration of the level of utilization of the production potential. On the other hand, it contributed to a decline in profitability (intensification of unfair competition practices) and an increase in debt.

Unfavorable trends in industrial production, and indirectly in agriculture and services, led to the deterioration of the situation on the labor market. Already in the first months of 1930, a decrease in the demand for labor was observed. Together with a decrease in production volume, an increase in inventories of unsold finished products, and a reduction in expenditures on investment, the demand for labor decreased, and the employers got rid of the employees they did not need (they rationalized employment and costs). In the following years, i.e., between 1931 and 1933, the above trend continued and there was a further decline in the number of workers. Therefore, unemployment increased [Jaros, 1969, pp. 130-131; Pabisz, 1956, pp. 511528; Pilch, 1968, pp. 232-235; Ziemba, 1961, pp. 480-481]. Data on the employment size in the Upper Silesian industry in the years of the Great Depression are presented in Table 2.

Table 2

Employment in the Upper Silesian industry in 1929-1933 (in thousand people)

\begin{tabular}{|c|c|c|c|c|}
\hline Year & Mining & $\begin{array}{c}\text { Metallurgy and } \\
\text { metal industry }\end{array}$ & $\begin{array}{c}\text { Other branches } \\
\text { of industry }\end{array}$ & Total \\
\hline 1929 & 97.5 & 41.9 & 70.4 & 210.2 \\
\hline 1930 & 84.6 & 37.7 & 54.3 & 176.6 \\
\hline 1931 & 75.8 & 32.3 & 43.3 & 151.6 \\
\hline 1932 & 57.2 & 21.7 & 33.8 & 112.7 \\
\hline 1933 & 48.2 & 24.1 & 32.4 & 104.7 \\
\hline
\end{tabular}

Source: AP Katowice, UWŚl-WP 224, pp. 103-112.

According to the data presented in Table 2, in the years of the crisis, reduction in employment affected all branches of the Upper Silesian industry to a varying degree. The presented data show that the redundancies mostly affected mining and steel industry (the leading branches of the lo- 
cal industry), and to a slightly lesser extent metallurgical, machine and construction industries. Respectively smaller changes in employment were recorded in industries producing consumer goods, and thus in the food, clothing and footwear industries.

Changes in the employment situation had a direct impact on the level of unemployment. Thus, the decline in employment between 1930 and 1933 meant an increase in the number of the unemployed in all branches of the Upper Silesian industry.

At the end of the first quarter of 1930, the number of people registered as unemployed increased. According to data from the State Employment Agency (PUPP - Państwowy Urzad Pośrednictwa Pracy), in the years 1930-1933 the number of the unemployed increased by over 60,000. people, i.e., by as much as $14.5 \%$. However, the data from PUPP did not present the actual size of unemployment, as they understated the number of jobseekers. They did not consider seasonal workers, workers without the right to unemployment benefit, and young people growing up to working age and seeking employment. More reliable data come from the reports of the Silesian Voivode, Michał Grażyński, prepared for the Ministry of the Interior (MSW). According to these data, the number of the unemployed in the discussed period fluctuated between 52.1 thousand in 1930 to 132.4 thousand in 1933 [AP Katowice, UWŚl - PH 2500 and UWŚl - PH 2635; "Labor Statistics" 1930-1933, employment agency; "Przegląd Gospodarczy" 1931, issue 3, p. 139; issue 6, p. 238; issue 7, p. 333; z. 8, p. 373; z. 9 , p. 414 ; z. 11, p. 483]. Data on the level of unemployment in the Upper Silesian industry in the years of the Great Depression are presented in Table 3.

Table 3

The number of unemployed people in Upper Silesia in 1929-1933 (in thousand people)

\begin{tabular}{|c|c|c|c|c|c|c|c|c|}
\hline Year & Miners & $\begin{array}{c}\text { Steelworkers } \\
\text { and } \\
\text { metalworkers }\end{array}$ & $\begin{array}{c}\text { Other } \\
\text { industries }\end{array}$ & $\begin{array}{c}\text { Unskilled } \\
\text { workers }\end{array}$ & $\begin{array}{c}\text { Other } \\
\text { professions }\end{array}$ & $\begin{array}{c}\text { White } \\
\text { collar }\end{array}$ & Juveniles & Total \\
\hline 1929 & 0.5 & 0.5 & 0.7 & 1.6 & 0.1 & 0.7 & 0.1 & 4.2 \\
\hline 1930 & 5.8 & 5.6 & 4.5 & 18.0 & 8.0 & 2.6 & 0.6 & 37.4 \\
\hline 1931 & 9.5 & 9.1 & 8.9 & 27.1 & 1.2 & 6.3 & 0.9 & 62.4 \\
\hline 1932 & 15.5 & 15.5 & 12.9 & 16.3 & 1.3 & 8.4 & 0.5 & 70.5 \\
\hline 1933 & 25.6 & 17.8 & 11.5 & 7.8 & 1.3 & 12.3 & 1.5 & 78.4 \\
\hline
\end{tabular}

Source: AP Katowice, UWŚL - PH 2547, pp. 48-49, 54-55. 
Fluctuations in the level of professional activity of hired employees had impact on the amount of their wages, and thus on the level of consumption. The decreasing employment triggered the mechanism of real wage decline (in the discussed period, income growth is observed only in the group of specialists), which led to the deterioration of the living conditions of Upper Silesian hired workers and people entitled to receive social benefits [Chlebowczyk, 1969, pp. 504-506; Derengowski, 1930, pp. 122-124]; "Górnośląskie Wiadomości Gospodarcze", 1936, pp. 330-331].

\section{Christian Democrat program to fight the crisis}

In 1926, significant changes in the balance of political forces in Poland were observed. The May Coup started the process of abandoning democracy. A new force, the Sanation (Sanacja) appeared on the political scene. After it had taken power, it implemented an apparent program of "repair" of economic and social relations.

The new political force outclassed the previously dominant camp of the Silesian Christian Democrats, the Christian Democracy (a nationalChristian camp), in the Upper Silesian part of the Silesian Voivodeship. Therefore, Wojciech Korfanty (the leader of the Christian Democrats and an antagonist of Michał Grażyński, the voivode and leader of the Silesian Sanation camp) was critical of the new political party. "The Sanation (Sanacja) system does not unite Silesia, it does not connect Polish ranks, but it breaks our society, it brings a division between Silesia and other regions, and creates aversion to the state, as the goals of this system are not the goals of the nation, because they are not in line with the interests of the state" [Korfanty, 1929]. According to Korfanty, the Sanation (Sanacja) undermined the existing legal (constitutional) order and it plainly violated democratic principles. On the one hand, it threatened the autonomous rights of the Silesian Voivodeship, i.e., self-governance and independence, and on the other hand, it harmed economic interests and undermined the fragile social and national order [Falęcki, 1987, pp. 4757; Krzywobłocka, 1974, pp. 103-114; Lewandowski, 2013, pp. 152-160; Lewandowski, 2014, pp. 19-28; Przybylski, 1980, pp. 85-98; "Polonia" of June 3, 1926].

Depending on the intensity of the decline in economic activity (the level of industrial production and employment) and the scale of social tensions, changes in the economic programs of the Silesian Christian Democrats were observed in the years of the Great Depression. In the initial phase 
of the gradual growth of economic and social problems, the Silesian Christian Democrats supported only the poorest, i.e., the weakest professional groups and their families. This attitude resulted from the common belief that the experienced economic difficulties were of a temporary character. Therefore, in the first year of the crisis, party activists formulated only minimalist proposals aimed at mitigating the negative effects of the deteriorating situation on the Silesian labor market. This was caused by the fact that growing unemployment primarily affected Polish workers and threatened fragile political stability (the proposals of the Christian Democrats emerged from the critical assessment of Sanation's (Sanacja) industrial policy, i.e., deflationary policies ruining industry and agriculture). The program formulated at that time emphasized the importance of ad hoc measures mitigating the decline in income and consumption of the local population. At this stage, the economic difficulties faced by local producers were ignored. Therefore, in their proposals, the Silesian Christian Democrats supported:

- defending the economically weaker, i.e., hired workers, against a drastic deterioration of living conditions (support, as part of an ad hoc aid operation, financed from the voivodeship's own funds),

- development of the public works program,

- financial support for agricultural producers ("price scissors" were ruining small family farms),

- support for widows, orphans and disabled people,

- improvement of housing conditions (municipal housing program),

- improvement of social legislation (common and fraternity) [Korfanty, 1930].

As the crisis deepened, the Christian Democrats changed their viewpoint, and alleviated the importance of the problem of the decline in employment and the deterioration of the financial situation of local workers. They drew attention to the deteriorating conditions for the functioning of enterprises (increased competition) and the decline in production profitability, primarily difficulties in selling local products both on the domestic and foreign market, because exports were regularly decreasing. They had a negative effect on both their financial condition and their attitude towards the Polish state. Korfanty and the entire organization of the Silesian Christian Democrats put the blame for this situation on the Sanation (Sanacja) government. According to them, the government could not make proper use of the good economic situation and wasted public funds on unnecessary investments (criticism of the statist actions of the Silesian voivode towards Upper Silesian enterprises). Considering the shortcomings of the Sanation 
(Sanacja) camp, Korfanty advocated the re-regulation of labor relations that would correspond to the changed economic and social realities. In their opinion, in the new economic and social realities, the state should guarantee the employees legal and tax protection (reducing the tax burden for small agricultural and industrial producers) as well as social protection. The Christian Democrats supported not only a large-scale adoption of pension insurance, but also insurance against the risk of work incapacity or illness. Therefore, they proposed introducing additional universal employee insurance (equivalents of fraternal insurance), allowing workers to have a share in profit of enterprises (the participation postulate was introduced), and limiting the number of high-paid positions in industry. Considering the above solutions in the economic policy was supposed to bring benefits to producers, employees (consumers) and the state. The proposed program did not show any specific ways of recovering from the crisis; it only presented ad hoc actions aimed at mitigating the negative consequences of the developing crisis ["Polonia" of May 11, 1930; "Polonia" from September 9, 1930].

In the opinion of the activists of the Silesian Christian Democrats, thoughtless economic policy in the liberal spirit contributed to the decline of trade, crafts and industry, and thus to an increase in unemployment, a decline in wages, a decrease in consumption and a growth of social unrest. While rejecting the Sanation (Sanacja), liberal, crisis-fighting programs, the Christian Democrats proposed their own policy, in which they suggested reforming the system, limiting the state's fiscalism, pro-family wages for workers, aid for small agricultural producers, support for Upper Silesian mining and metallurgical producers and a more effective way of tackling unemployment. The view about the harmfulness of the Sanation (Sanacja) program to combat the crisis was reflected in the resolution of the Silesian Sejm: "The Silesian Sejm demands regulations from the Government of the Republic of Poland, and submitting to legislative bodies, the projects that would fairly distribute the existing amount of work and increase the opportunity to work by undertaking public works, facilitating loans and commissioning orders. As far as closing workshops and firing workers are concerned, the Silesian Sejm demands the implementation of the second part of the act on Works Councils so that workers have the opportunity to control the economy in industrial enterprises" [Transcript of III Silesian Sejm, 1931, p. 54]. On the basis of the above resolution, under the influence of the Silesian Christian Democrats, the Labor and Social Welfare Commission formulated a number of postulates aimed at healing the economic situation through: 
- abandoning the export policy based on dumping (promoting exports at the expense of the domestic consumer),

- internationalization of the regulation of coal prices in order to stop the decline in the prices of the product on the domestic market,

- centralization of coal sales in one nationwide coal syndicate,

- revitalizing the domestic market by reducing administrative costs and introducing elements of the state economy (there was support for state activity in the real sphere, but in the Christian spirit and social and class solidarity),

- agricultural reform, aimed at eliminating the source of the specific agricultural structure (under the provisions of the Geneva Convention, in Silesian agriculture, the elements of the feudal structure of farms were still observed) affecting social relations (the Christian Democrats wanted to strengthen the position of the peasant population that in vast majority was Polish),

- change of staff policy in enterprises in Upper Silesia (it was demanded to abandon hiring incompetent people in highly paid positions),

- limiting the employment of foreigners in the Upper Silesian industry [Transcript of III Silesian Sejm, 1932].

Sanation (Sanacja) program to combat the crisis was severely criticized at the 4th Congress of the Polish Party of Christian Democracy that was held in Łódź in November 1932. The participants of the Congress rejected the Sanation (Sanacja) deflation policy because it intensified the experienced economic difficulties and aggravated the financial situation of the entire Polish society. In his speech during the congress, Korfanty said that the source of the ongoing crisis lied in the capitalist economy system, and therefore in the pursuit of profit. The motive of individual benefits led to an unfair distribution of the generated national income, and thus to the poverty of the extensive masses of workers. It also widened the gap between the rich and the poor (it accelerated the process of society polarization). Moreover, this motive contributed to the collapse of small family farms in agriculture and to the destruction of the Polish lower middle class (small-scale producers), as well as to overproduction (crises) and mass unemployment. "For us, capitalism is the greatest evil and misfortune of humankind and therefore we must constantly work to abolish it and replace it with the Christian system. We are the opponents of capitalism, both state and private" [Lewandowski, 2013, p. 178]. According to Korfanty, the crisis of capitalism inevitably led to increased social unrest and deterioration of the operating conditions for domestic producers. Based on the theses presented in Korfanty's speech, the Congress participants formulated new 
program assumptions that included the following political and economic postulates:

- building a corporate welfare state (the weakness of Polish democracy under the Sanation (Sanacja) rule pushed Christianity onto the path of the concept of a corporate state based on Christian values, i.e., on Leo XIII's Encyclical Rerum Novarum),

- implementation of land reform (parceling of state land to landless and small-scale farmers),

- protection of the economic interest of the bourgeoisie, i.e., Polish crafts and small-goods producers (the mainstay of capitalism was defended in Polish realities),

- socialization of basic natural resources and partial expropriation of private property (especially large industrial property belonging to foreign capital, and consciously threatening the economic interests of the Polish state),

- workers' participation not only in the distribution of the generated profit, but also in the management of enterprises ["Polonia" of November 6 and 7, 1932; "Polonia" from March 11, 1934; "Polonia" from April 13, 1934; Przybylski, 2003, p.].

The Christian Democratic programs to combat the crisis contained only a catalogue of postulates, but did not answer such fundamental questions as: (1) What are the sources of the crisis? and, (2) What needs to be done to improve the economic situation? The Christian Democrats were only trying to "adapt" their modified programs to the prevailing realities, which was connected with the criticism of the Sanation (Sanacja) crisis-combating programs: "(...) the present crisis cannot lead back to the same structure of relations that existed before the resettlement. It must lead to a social reconstruction towards replacing the capitalist system with a new system based on the privileges of the working and producing class" ["Polonia" of November 6 and 7, 1932].

\section{Conclusions}

The great economic crisis surprised both the rulers and politicians representing the Polish political scene. Due to the fact that the rulers and politicians did not have adequate economic knowledge, they only initiated ad hoc measures, mitigating and not removing the causes of the economic crisis. The Silesian Christian Democrats and their leader Wojciech Korfanty were in a similar situation. Under the influence of the experienced 
economic and social difficulties, as well as specific economic and national conditions, Korfanty, along with other activists, changed their point of view on the economy, and especially on ownership relations. Therefore, during the crisis years, the Christian Democrats formulated economic programs (gradually modified and supplemented), in which they advocated the reconstruction of the existing socio-economic (institutional) relations, including the transformation of the liberal state into a corporate social state (based on Christian ethics and social solidarity). The reconstruction of the economic system was associated with the recovery of agricultural relations, with the socialization and partial expropriation of private property (limitation of the possession of German capital) and with the protection of the middle class and small-scale producers as the fundament for the efficient functioning of society in the economic dimension.

The programs for combating the crisis proposed by the Silesian Christian Democrats did not present an in-depth analysis of its causes, as the political view dominated the economic one. Therefore, they adapted to the already existing conditions, and in this perspective, the Sanation (Sanacja) was blamed for the deterioration of the operating conditions of enterprises and the growing social and political tensions.

\section{B I B L I O G R A P H Y}

\section{Archival materials}

AP Katowice, UWŚl - PH 2500.

AP Katowice, UWŚl - PH 2635.

"Statystyka Pracy" ["Labor Statistics"] 1930-1933, employment agency.

Transcript of the III Silesian Sejm, session 12 of November 23, 1931, p. 54.

Transcript of the III Silesian Sejm, session 14 from January 14, 1932.

\section{Press and magazines}

"Górnośląskie Wiadomości Gospodarcze"

"Polonia"

"Przegląd Gospodarczy"

\section{Articles and studies}

Chlebowczyk J. (1969), Zarobki górnicze na Górnym Śląsku w okresie międzywojennym, (in:) Studia i materiały z dziejów Śląska, vol. IV, pp. 504-506.

Danowska-Prokop B. (2012), Sytuacja gospodarcza i społeczna na Górnym Śląsku w okresie międzywojennym i jej wpływ na ubezpieczenia brackie, Wydawnictwo Uniwersytetu Ekonomicznego w Katowicach, Katowice. 
Danowska-Prokop B., Zagóra-Jonszta U. (2017), Wybrane problemy ekonomicznospołeczne i polityczne na Górnym Śląsku w latach 1922-1939 (źródła regionalizmu), Wydawnictwo Uniwersytetu Ekonomicznego w Katowicach, Katowice.

Derengowski J. (1930), Płace robotników przemysłowych w Polsce w latach 19241929, "Statystyka Pracy" z. 1, pp. 122-124.

Dobis N., Polski przemysł węglowy w 1930 roku, "Przegląd Gospodarczy" 1931, z. 9 , pp. $382-387$.

Dobis N., Polski przemysł węglowy w 1931 roku, "Przegląd Gospodarczy" 1932, z. 9, pp. 353-358.

Falęcki T. (1987), Klub poselski Chrześcijańskiego Zjednoczenia Ludowego w Sejmie Śląskim, (in:) Studia i materiały z dziejów Śląska, vol. XVI, pp. 47-57.

Grzyb M. (1978), Narodowościowo-polityczne aspekty przemian stosunków własnościowych i kadrowych w górnośląskim przemyśle w latach 1922-1939, Wydawnictwo Uniwersytetu Śląskiego, Katowice.

Horowitz E., Sytuacja w hutnictwie żelaza Górnego Śląska, "Śląskie Wiadomości Gospodarcze" 1932, nr 3, pp. 51-52.

Jaros J. (1969), Historia górnictwa węglowego w Zagłębiu Górnośląskim w latach 1914-1945, PWN, Katowice-Kraków.

Jaros J. (1974), Kryzys gospodarczy w polskim przemyśle węglowym (19301933), (in:) Wielki kryzys gospodarczy 1929-1933 na Śląsku i w Zagłębiu Dąbrowskim oraz jego społeczne konsekwencje, ed. J. Chlebowczyk, Śląski Instytut Naukowy, Katowice.

Kongres Polskiego Stronnictwa Chrześcijańskiej Demokracji w Łodzi. Przebudowa ustroju gospodarczego, "Polonia" of November 6 and 71932.

Korfanty W., Wybory do Sejmu Śląskiego, "Polonia" of April 4, 1930.

Korfanty W., Czasowi do pamiętnika, "Polonia" of December 18, 1929.

Krzywobłocka B. (1974), Chadecja 1918-1937, "Książka i Wiedza", Warszawa.

Lewandowski J. F. (2013), Wojciech Korfanty, Państwowy Instytut Wydawniczy, Warszawa.

Lewandowski J. F. (2014), Korfanty wobec śląskiej autonomii, (in:) Oni decydowali na Górnym Śląsku z XX wieku, ed. J. Mokrosz i M. Węcki, Archiwum Państwowe w Katowicach, Stowarzyszenie Humanistyczne Europa, Śląsk, Świat Najmniejszy, Katowice-Rybnik.

Liczba bezrobotnych w Polsce, "Przegląd Gospodarczy" 1931, z. 3, pp. 139; z. 5, p. 238 ; z. 6 , p. 284 ; z. 7 , p. 333 ; z. 8, p. 373 ; z. 9 , s. 414 ; z. 11 , p. 483.

Nowy Prezydent Rzeczypospolitej, "Polonia" of June 3, 1926.

Ostatnie słowa, "Polonia" of May 11, 1930.

Pabisz J. (1956), Zatrudnienie robotników za rewersem w był województwie śląskim w latach trzydziestych XX wieku, (in:) Studia i materiały z dziejów Śląska, ed. K. Popiołek, t. II, Wrocław, pp. 511-528. 
Pilch A. (1968), Czas pracy w przemyśle Górnego Śląska (części polskiej) i Zagłębia Dąbrowskiego w okresie międzywojennym, (in:) Studia i materiały z dziejów Śląska, vol. IX, Katowice, pp. 232-235.

Popkiewicz J. Ryszka F. (1959), Przemysł ciężki Górnego Śląska w gospodarce Polski międzywojennej. Studium historyczno-gospodarcze, Instytut Śląski w Opolu, Opole.

Przybylski H. (1980), Chrześcijańska Demokracja i Narodowa Partia Robotnicza w latach 1926-1937, PWN, Warszawa.

Przybylski H. (2003), Ewolucja programu politycznego Wojciecha Korfantego, (in:) Wojciech Korfanty 1873-1939. W 130 rocznice urodzin, ed. T. Kulak, Instytut Historyczny Uniwersytetu Wrocławskiego, Wrocław.

Śląska ChD a centrolew, "Polonia" of September 9, 1930.

Walka z bezrobociem na Śląsku, "Górnośląskie Wiadomości Gospodarcze" 1936, nr 13/14, pp. 330-331.

Wanatowicz M. (1970), Przemysł metalowy na Śląsku i w Zagłębiu Dąbrowskim w okresie międzywojennym (fragmenty kartoteki zakładów przemysłowych), (in:) Studia i materiały z dziejów Śląska" vol. X, pp. 385-423.

Wiliński F. (1930), Kryzys gospodarczy w Polsce, "Śląskie Wiadomości Gospodarcze" nr 1, pp. 5-7.

Ziemba J. (1961), Liczebność i struktura proletariatu polskiej części Górnego Śląska i Zagłębia Dąbrowskiego w okresie międzywojennym, (in:) Studia i materiały z dziejów Śląska, red. J. Chlebowczyk, K. Popiołek, vol. IX, WrocławWarszawa-Kraków, pp. 480-481. 